\title{
Microwave Assisted Synthesis, Characterization and Antimicrobial Study of Substituted Benzo-(5,6-e)-[1,3]- diazepine-4,7-dione Derivatives
}

\author{
RAJESH M. KHARATE*, PRADIP P. DEOHATE ${ }^{\mathrm{a}}$ and B. N. BERAD ${ }^{\mathrm{b}}$ \\ *Department of Chemistry, Shri Sant Gajanan Maharaj College of Engineering, Shegaon, \\ Dist.-Buldhana, India \\ ${ }^{a}$ Department of Chemistry, Shri Radhakisan Laxminarayan Toshniwal College of Science, \\ Akola, India \\ ${ }^{\mathrm{b}}$ Department of Chemistry, Rashtrasant Tukadoji Maharaj Nagpur University, Nagpur, India \\ rmkharate@rediffmail.com
}

Received 2 July 2012 / Accepted 28 July 2012

\begin{abstract}
Synthesis of series of [benzo-(5,6-e)-1,3-diphenyl-2-arylimino-[1,3]-diazepine]-4,7-dione hydrochlorides have been achieved by the interaction of $N, N$-diphenyl phthalamide with $N$-aryl isocyanodichlorides by irradiation in a domestic microwave oven for specified time using little chloroform as a solvent along with potassium carbonate. The hydrochlorides were then basified with dilute ammonium hydroxide solution. The parent compound $N, N$-diphenyl phthalamide was obtained by refluxing the mixture of phthalic anhydride and aniline in toluene. The structures of synthesized compounds were established on the basis of chemical transformation, elemental analysis, IR, ${ }^{1} \mathrm{H}$ NMR and Mass spectral studies. The synthesized compounds have been assayed for their antimicrobial activity against gram-positive as well as gram-negative microorganisms.
\end{abstract}

Keywords: Benzodiazepine-di-ones, Microwave assisted synthesis, Antimicrobial activity

\section{Introduction}

Synthesis of few benzo-fused heterocycles has been reported earlier ${ }^{1-6}$. Pyrallo benzo-fused heterocycles have been shown to have anti-HIV-1 and anti-HIV-1RT inhibitory activity comparable to nevirapine ${ }^{7-8}$. The synthesis of benzo-fused diazepines have been reported earlier by conventional method. Synthetic applications of $N$-aryl isocyanodichloride ${ }^{9,10}$ have been investigated earlier and shown to have enough potentiality in the synthesis of nitrogen and sulphur containing heterocyclic compounds ${ }^{11-14}$. In view of the utility of $N$-aryl isocyanodichlorides in the synthesis of heterocyclic compounds and as a part of wider programme to provide alternative routes of synthesis, now the microwave assisted method for synthesis of benzo-fused diazepines is reported. 


\section{Experimental}

The melting points of all synthesized compounds were recorded using hot paraffin-bath and are uncorrected. Chemicals used were of AR grade. ${ }^{1} \mathrm{H}$ NMR spectra were recorded on VARIAN, USA Mercury Plus $300 \mathrm{MHz}$ spectrometer with TMS as internal standard using $\mathrm{CDCl}_{3}$ and DMSO- $d_{6}$ as solvents. IR spectra were recorded on MAGNA, USA 550 spectrophotometer in the frequency range $4000-50 \mathrm{~cm}^{-1}$. Mass spectra were recorded on VARIAN, USA 410 Prostar Binary LC with 500 MS IT PDA Detector. Purity of the compounds was checked on silica gel-G plates by TLC.

\section{Synthesis of $N, N$-diphenyl phthalamide (2)}

The compound $N, N$-diphenyl phthalamide (2) was prepared by refluxing the mixture of phthalic anhydride 1, (0.01 mole) and aniline (0.02 mole) in toluene (10 mL) for $3 \mathrm{~h}$. The reaction mixture was cooled, toluene was distilled off and the solid residue obtained was crystallised from aqueous ethanol, 2 (70\%), m.p. $148{ }^{\circ} \mathrm{C}$.

Synthesis of [benzo-(5,6-e)-1,3-diphenyl-2-phenylimino-[1,3]-diazepine]-4,7-dione (5a)

The mixture of $N, N$-diphenyl phthalamide 2, (0.01 mole) and $N$-phenyl isocyanodichloride 3 , (0.01 mole) was irradiated in a domestic microwave oven $(200 \mathrm{~W})$ for specified time using little chloroform as a moistening agent along with potassium carbonate (0.01 mole). On cooling the reaction mixture granular solid was obtained. It was acidic to litmus, crystallized from aqueous ethanol (75\%) and on titrimetric analysis identified as [benzo(5,6-e)-1,3-diphenyl-2phenylimino-[1,3]-diazepine]-4,7-dione hydrochloride 4a. Similarly, other compounds, $\mathbf{4 b}$-g were prepared.

On basification of $\mathbf{4 a}$ with dilute ammonia solution a free base $\mathbf{5 a}$ was obtained, it was crystallised from aqueous ethanol, m.p. $291{ }^{\circ} \mathrm{C}$ (Found: C, 77.32; H, 4.32; N, 10.02. Calcd. for $\mathrm{C}_{27} \mathrm{H}_{19} \mathrm{~N}_{3} \mathrm{O}_{2}$ : C, 77.69; H, 4.55; N, 10.07\%); IR: $1684(\mathrm{C}=\mathrm{O}), 1593(\mathrm{C}=\mathrm{N}), 1321 \mathrm{~cm}^{-1}$ $(\mathrm{C}-\mathrm{N})^{17,18} ;{ }^{1} \mathrm{H}$ NMR $\left(\mathrm{CDCl}_{3}+\mathrm{DMSO}-d_{6}\right): 6.83-7.86(19 \mathrm{H}, \mathrm{m}, \mathrm{Ar}-\mathrm{H}) ; \mathrm{MS}: \mathrm{m} / \mathrm{z} 417\left(\mathrm{M}^{+}\right), 340$ $\left(\mathrm{M}^{+}-\mathrm{C}_{6} \mathrm{H}_{5}\right), 326\left(\mathrm{M}^{+}-\mathrm{C}_{6} \mathrm{H}_{5} \mathrm{~N}\right), 263\left(\mathrm{M}^{+}-2 \mathrm{C}_{6} \mathrm{H}_{5}\right)$. Similarly, free base $5 \mathbf{b}$ was prepared from 4b: 5b, m.p. $299{ }^{0} \mathrm{C}$ (Found: C, 77.66; H, 4.14; N, 9.11. Calcd. for $\mathrm{C}_{28} \mathrm{H}_{21} \mathrm{~N}_{3} \mathrm{O}_{2}$ : C, 77.95; $\mathrm{H}$, 4.87; N, 9.74\%); IR: $1688(\mathrm{C}=\mathrm{O}), 1541(\mathrm{C}=\mathrm{N}), 1325 \mathrm{~cm}^{-1}(\mathrm{C}-\mathrm{N}) ;{ }^{1} \mathrm{H}$ NMR $\left(\mathrm{CDCl}_{3}+\mathrm{DMSO}_{6}\right)$ ): 6.83-7.86 (18H, m, Ar-H), $2.13\left(3 \mathrm{H}, \mathrm{s}, \mathrm{Ar}-\mathrm{CH}_{3}\right)$; MS: $\mathrm{m} / \mathrm{z} 431\left(\mathrm{M}^{+}\right), 105\left(\mathrm{NC}_{6} \mathrm{H}_{4} \mathrm{CH}_{3}{ }^{+}\right)$. This reaction was extended to synthesize other free bases, 5c-g: 5c, m.p. $295{ }^{0} \mathrm{C}$ (Found: $\mathrm{C}$, 77.54; H, 4.19; N, 9.24. Calcd. for $\mathrm{C}_{28} \mathrm{H}_{21} \mathrm{~N}_{3} \mathrm{O}_{2}$ : C, 77.95; H, 4.87; N, 9.74\%); 5d, m.p. $288{ }^{0} \mathrm{C}$ (Found: C, 77.70; H, 4.56; N, 9.60. Calcd. for $\mathrm{C}_{28} \mathrm{H}_{21} \mathrm{~N}_{3} \mathrm{O}_{2}$ : C, 77.95; H, 4.87; N, 9.74\%); 5e, m.p. $286{ }^{\circ} \mathrm{C}$ (Found: C, 71.56; H, 3.63; N, 9.10. Calcd. for $\mathrm{C}_{27} \mathrm{H}_{18} \mathrm{~N}_{3} \mathrm{O}_{2} \mathrm{Cl}$ : C, 71.76; H, 3.98; N, 9.30\%); 5f, m.p. $297^{\circ} \mathrm{C}$ (Found: C, 71.63; H, 3.66; N, 9.05. Calcd. for $\mathrm{C}_{27} \mathrm{H}_{18} \mathrm{~N}_{3} \mathrm{O}_{2} \mathrm{Cl}$ : C, 71.76; H, 3.98; N, 9.30\%); 5g, m.p. 288 $\mathrm{C}$ (Found: C, 71.45; H, 3.65; N, 9.18. Calcd. for $\mathrm{C}_{27} \mathrm{H}_{18} \mathrm{~N}_{3} \mathrm{O}_{2} \mathrm{Cl}$ : C, 71.76; H, 3.98; N, 9.30\%).

\section{Results and Discussion}

The parent compound $N, N$-diphenyl phthalamide (2) was prepared by refluxing the mixture of phthalic anhydride 1, (0.01 mole) and aniline (0.02 mole) in toluene $(10 \mathrm{~mL})$ for $3 \mathrm{~h}$. Compound 2 was then reacted with $N$-aryl isocyanodichlorides by irradiating the mixtures in a microwave oven $(200 \mathrm{~W})$ for specified time using little chloroform as a moistening agent along with potassium carbonate. On cooling the reaction mixtures granular solids were obtained. These were acidic to litmus and on titrimetric analysis identified as [benzo-(5,6-e)1,3-diphenyl-2-arylimino-[1,3]-diazepine]-4,7-dione hydrochlorides 4a-g. These on basification with aqueous ammonia solution afforded free bases 5a-g (Scheme 1). 


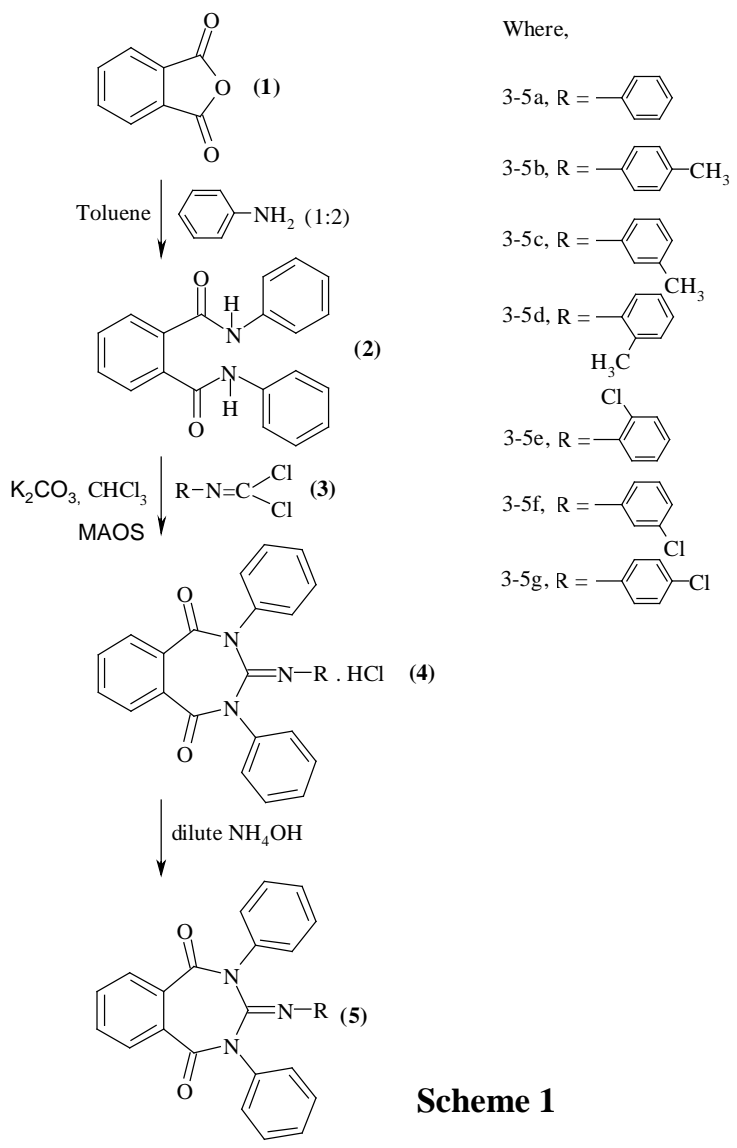

\section{Antimicrobial activity}

The synthesized compounds 5a-g were screened for their antibacterial activity using cup plate diffusion method ${ }^{15,16}$. The bacterial organisms used included both gram-positive as well as gram-negative strains like E. coli, S. aureus, S. typhi, B. subtilis and A. aerogenes. Sensitivity plates were seeded with a bacterial innoculum of $1 \times 10^{6} \mathrm{CIU} / \mathrm{mL}$ and each well (diameter $10 \mathrm{~mm}$ ) was loaded with $0.1 \mathrm{~mL}$ of test compound solution $(1000 \mu \mathrm{g} / \mathrm{mL})$ in DMF, so that concentration of each test compound was $100 \mu \mathrm{g} / \mathrm{mL}$. The zones of inhibition were recorded after incubation for $24 \mathrm{~h}$ at $37{ }^{\circ} \mathrm{C}$, using Vernier caliper. Inhibition zone record of the compounds clearly indicated that $\mathbf{5 d}$ and $\mathbf{5 f}$ were highly active against $B$. subtilis and moderately active against $E$. coli. Majority of the compounds were found inactive against $S$. aureus and $A$. aerogenes.

\section{Acknowledgement}

Thanks are due to Head, S.A.I.F., Indian Institute of Technology Bombay, IIT Powai, Mumbai for providing analytical and spectral data. Authors are also thankful to Dr. V. N. Gohokar, Principal, Shri Sant Gajanan Maharaj College of Engineering, Shegaon and Dr. V. G. Thakare, Principal, Shri Shivaji Science College, Amravati for providing necessary facilities. 


\section{References}

1 Kusanur R A, Ghate M and Kulkarni M V, J Chem Sci., 2004, 116(5), 265-270.

2 Lattmann E, Sattayasai J, Billington D C, Poyner D R, Puapairoj R, Tiamkao S, Airarat W, Singh H and Offel M, J Pharm., 2002, 54, 827.

3 Silvestri R, Pagnozzi E, Stefancich G and Artico M, Synthetic Comm., 1994, 24, 2685-2695.

4 Anwar B, Grimsey P, Hemming K, Krajniewski M and Loukou C, Tetrahedron Lett., 2000, 41, 10107-10110.

5 Kalluraya B, Vishwanatha P, Hegde Jyothi C, Frank Priya V and Raj G, Indian J Heterocycl Chem., 2003, 12(4), 355-356.

$6 \quad$ Lattmann E, Poyner D R, Offel M and Arayarat P, Science (KKU), 2002, 30, 114-125.

7 Silvestri R, Artico M, Pagnozzi E, Massa S, La Colla P, Loi A G, Spiga M G, Corrias S and Lichino D, Farmaco, 1996, 51(6), 425-430.

8 Artico M, Silvestri R, Pagnozzi E, Stefancich G, Massa S, Loi A G, Putzolu M, Corrias S, Spiga M G and La Colla P, J Bioorg and Med Chem., 1996, 4(6), 837-850.

9 Dyson G M and Harington J, J Chem Soc., 1940, 191.

10 Thomas M Krulle and Jac C H M Nijkmans, Tetrahedron, 2001, 57, 7021.

11 Kuhle E, Anders B, Klauke E, Tarnow H and Zumach G, Angew Chem., 1969, 81, 18-32.

12 Pathe P P and Paranjpe M G, Indian J Chem., 1981, 20, 824.

13 Walter W and Hell P M, Justus Liebig's Ann., 1969, 22, 727.

14 Deohate P P and Berad B N, Indian J Chem., 2005, 44B, 683.

15 Barry A L, The Antimicrobial Suspectibility test; Principle and practices, Edited by Illus Lea and Fibiger (Philadephia, Pa, U S A), 1976, 180.

16 Cavanagh F, Analytical Microbiology, (Academic Press, New York), 1963, 126.

17. Colthup N B, Daly L H and Wiberly S E, Introduction to Infrared and Raman Spectroscopy, (Academic Press, New York), 1964.

18. Silverstein R M, Bassler G C and Morril T C, Spectrometric Identification of Organic Compounds, $4^{\text {th }}$ Edn., (John Wiley \& Sons, New York), 1981. 